\title{
PERBEDAAN PRESTASI BELAJAR MATEMATIKA DITINJAU DARI TIPE KEPRIBADIAN SISWA DALAM PEMBELAJARAN MATEMATIKA
}

\author{
Dwi Oktaviana ${ }^{1}$, Utin Desy Susiaty ${ }^{2}$ \\ Prodi Pendidikan Matematika, IKIP PGRI Pontianak ${ }^{1,2}$ \\ Email: dwi.oktaviana7@gmail.com ${ }^{1}$
}

\begin{abstract}
Abstrak
Penelitian ini bertujuan untuk mengetahui perbedaan yang signifikan prestasi belajar matematika ditinjau tipe kepribadian siswa (Sanguinis, Melankolis, Koleris, dan Plegmatis). Penelitian ini merupakan penelitian eksperimen semu (quasi eksperimental) dengan rancangan penelitian yang digunakan adalah Factorial Design. Populasi dalam penelitian ini adalah semua siswa kelas X MIA SMA Negeri 3 Pontianak. Sampel diambil dengan teknik purposive sampling. Data yang dikumpulkan adalah prestasi belajar matematika dan angket. Nilai prestasi belajar didapat dari tes prestasi belajar bentuk pilihan ganda. Angket yang digunakan adalah angket tes tipe kepribadian (Sanguinis, Melankolis, Koleris, dan Plegmatis). Data dianalisis dengan uji analisis variansi satu jalan (One Way Anova). Hasil penelitian menunjukkan bahwa tidak terdapat perbedaan yang signifikan prestasi belajar matematika siswa antar tipe kepribadian (Sanguinis, Plegmatis, Koleris, Melankolis). Dibuktikan dari hasil analisis diperoleh $f_{\text {hitung }}=0,139<f_{\text {tabel }}=2,92$.
\end{abstract}

Kata kunci:prestasi belajar siswa, tipe kepribadian sanguinis, plegmatis, koleris, melankolis

\section{Abstract}

This study aims to find significant differences in mathematics learning achievement of students with personality types (Sanguine, Melancholic, Choleric, Phlegmatic). It is a quasi-experimental study using Factorial Design as its research design. The population of this study is all students from class $X$ MIA SMA Negeri 3 Pontianak. Samples are taken applying a purposive sampling technique. The collected data are in the form of mathematics learning achievement and questionnaire. The scores of learning achievement are obtained from multiple-choice tests. The questionnaire distributed is a test of personality types (Sanguine, Melancholic, Choleric, Phlegmatic). Data are analyzed using One Way Analysis of Variance (Anova). The results show there are significant differences in mathematics learning achievement of students with personality types (Sanguine, Melancholic, Choleric, Phlegmatic), as proved in the results of the analysis $f_{h}=0,139<f_{t}=2,92$.

Keywords: Learning achievement of student, personality types of sanguine, melancholic, choleric, phlegmatis

\section{PENDAHULUAN}

Mata pelajaran matematika banyak memuat konsep-konsep dan prinsip-prinsip yang sukar dipahami, selain itu dalam matematika juga memuat rumus dan perhitungan dalam setiap pemecahan masalah.

Banyak siswa mulai dari SD, SMP maupun SMA beranggapan mata pelajaran matematika sebagai pelajaran yang sulit karena beberapa faktor yang ada, baik faktor dari siswa, guru maupun lingkungan.Kurangnya kemampuan guru dalam penguasaan kelas dan kegiatan belajar mengajar yang monoton membuat siswa merasa bosan dan kurang memperhatikan pelajaran yang disampaikan, hal tersebut yang membuat banyak siswa kurang tertarik dengan mata pelajaran matematika. Kegiatan belajar hendaknya menjadi prioritas,terlebih belajar untuk kepentingan masa depan atau belajar untuk mengantisipasi realitas di masa yang akan datang. Belajar itu adalah memang sifatnya jiwa manusia. Kegiatan belajar menjadi semakin penting bagi anak dan remaja yang hidup dalam 
era globalisasi yang menuntut keterbukaan dan kelenturan dalam berpikir, serta kemampuan memecahkan masalahmasalah non-rutin secara kreatif dan kritis[1]. Sejauh ini kegiatan belajar masih merupakan kewajiban yang harus siswa lakukan karena aturan dari orang tua siswa.

Keberhasilan dalam kegiatan belajar itu bukanlah suatu perkara yang mudah karena keberhasilan belajar sangat dipengaruhi oleh banyak faktor antara lain faktor internal dan factor eksternal [2]. Faktor internal merupakan faktor yang ada dalam diri individu yang sedang belajar, antara lain: faktor jasmani, faktor kelelahan, dan faktor psikologis, sedangkan faktor ekstern adalah faktor yang ada di luar individu yang digolongkan menjadi tiga kelompok, yaitu: faktor keluarga, faktor sekolah, dan faktor masyarakat. Berdasarkan pendapat tersebut guru harus mengetahui dan memperhitungkan bahwa terdapat perbedaan karakteristik kepribadian siswa yang disebabkan oleh perbedaan pengaruh, baik dari faktor intern maupun ekstern karena dapat mempengaruhi jalannya proses dan hasil belajar siswa yang bersangkutan. Karakteristik kepribadian seseorang tampak pada dirinya dalam berbagai bentuk sikap, cara berpikir, dan cara bertindak. Sikap, cara berpikir, dan bertindak itu dapat dipastikan tidak selalu sama antar individu yang satu dengan yang lain begitu pula dengan karakteristik kepribadian siswa yang berbeda dalam mengikuti kegiatan belajar mengajar mengakibatkan perbedaan prestasi belajar atau hasil belajar yang berbeda pula. Salah satu faktor yang menentukan prestasi belajar siswa salah satunya adalah tipe kepribadian siswa.

Kepribadian siswa tercermin dari pola dan ciri-ciri perilaku mereka seperti suka bekerja keras, disiplin, pemalu, santai atau suka menyendiri. Setiap orang memiliki kepribadian. Kepribadian setiap orang tidaklah sama, dan masing masing memiliki tipe kepribadian tersendiri. Ada banyak tipe kepribadian, seperti diungkapkan oleh parah ahli. Tipe-tipe kepribadian telah banyak diungkapkan oleh para ahli psikologi, antara lain: tipe hardiness (kepribadian ketabahan), tipe kepribadian introver-ekstrover, kepribadian tipe A dan tipe B, kepribadian oral, anala, dan kepribadian phallic, tipe kepribadian sanguinis, melankolis, koleris, dan plegmatis, serta lain sebagainya. Setiap dimensi dasar kepribadian memiliki ciri-ciri yang saling bertolak belakang.Hasil penelitian yang berhubungan dengan kepribadian telah dilakukan oleh [3] yang berjudul "Perbedaan Prestasi Belajar Ditinjau dari Tipe Kepribadian Ekstrovert-Introvert pada Mahasiswa Universitas Negeri Malang". Hasil penelitian menunjukkan bahwa mahasiswa Universitas Malang sebagian besar berkepribadian ekstrovert yang memiliki predikat prestasi sangat memuaskan. Sementara itu, [4] telah melakukan penelitian yang berjudul "Analisis Prestasi Belajar Matematika Siswa Berkepribadian Introvert dan Siswa Berkepribadian Ekstrovert". Hasil penelitian yang diperoleh menunjukkan bahwa tidak adanya perbedaan rata-rata nilai signifikan pada siswa berkepribadian introvert dan berkepribadian ekstrovert. Namun pada kenyataannya, kemampuan dan kecerdasan kognitif siswa sering dikaitkan dengan kepribadian ekstrovert. Kepribadian extrovert cenderung lebih cepat mengeluarkan pendapat, kreatif dan lebih bersikap terbuka. Sebaliknya tipe kepribadian introvert cenderung santai, kurang berani mengambil resiko atau hatihati setiap mengambil keputusan, menutup diri dan pasif. Begitu juga dengan kepribadian tipe A dan tipe B yang saling bertolak belakang. 
Sebuah artikel yang dilansir oleh Kedaulatan Rakyat pada 25 Agustus 2012 berjudul Kepribadian Siswa Mempengaruhi Kelulusan mengungkapkan bahwa kepribadian siswa mampu mempengaruhi kelulusan ujian sekolah. Kepribadian siswa merupakan poin yang menjadi pertimbangan dalam penentuan kelulusan prestasi belajar. Kelulusan dan keberhasilan belajar peserta didik tidak hanya ditentukan oleh nilai akademik tetapi juga karakter yang dimiliki siswa. Perubahan format syarat kelulusan yang mempertimbangkan karakter peserta didik akan menjadi target di masa mendatang, ini sesuai yang diungkapkan Baskara Aji selaku Kepala Dinas Pendidikan Pemuda dan Olah Raga (Disdikpora) DIY. Penilaian kepribadian diharapkan tidak hanya menciptakan lulusan yang cerdas secara akademik tetapi juga mental dan spiritual sehingga generasi masa depan akan memiliki etos kerja yang baik,akhlak mulia, memiliki jiwa kepemimpinan dan menghindari perilaku negatif.

Hiprocates dan Gelanus dalam [5], membagi tipe kepribadian berdasarkan zat cair yang ada dalam tubuh seseorang. Berdasarkan pemikirannya, ia mengatakan bahwa keempat tipe temperamen dasar itu adalah akibat dari empat macam cairan tubuh yang sangat penting di dalam tubuh manusia. Berikut adalah uraiannya: (1) Sifat kering terdapat dalam chole (empedu kuning), (2) Sifat basah terdapat dalam melanchole (empedu hitam), (3) Sifat dingin terdapat dalam phlegma (lendir), dan (4) Sifat panas terdapat dalam sanguis (darah). Mereka membagi tipe kepribadian ke dalam empat bagianyaitu: sanguinis, melankolis, koleris, dan plegmatis. Beberapa sumber yang menjelaskan tipe kepribadian Hipocrates-Galenus, menyebutkan bahwa seorang sanguinis pada umumnya memiliki tingkah laku suka berbicara, penuh semangat, penuh rasa ingin tahu, kreatif dan inovatif, mudah bergaul. Seorang melankolis memiliki sifat tekun, perasa terhadap orang lain, penuh pikiran, gigih dan cermat. Seorang koleris memiliki daya juang besar, berbakat pemimpin, dinamis, aktif, berkemauan kuat, tegas, berkembang karena saingan, dan seorang plegmatis memiliki sifat sabar, tenang, mudah bergaul, santai, tidak mudah marah.

Berdasarkan hal-hal yang telah dijelaskan peneliti bermaksud untuk mengetahui perbedaan yang signifikan prestasi belajar matematika ditinjau dari beberapa tipe kepribadian siswa yaitu sanguinis, melankolis, koleris, dan plegmatis.

\section{METODE}

Penelitian ini merupakan penelitian eksperimen yang dilaksanakan di SMA Negeri 3 Pontianak. Populasi dalam penelitian ini adalah seluruh siswa kelas XMIA SMA Negeri 3 Pontianak. Sampel yang diambil dalam penelitian iniadalah siswa kelas X MIA3 dengan jumlah siswa sebanyak 39 siswa. Teknik pengambilan sampel yang digunakan adalah purposive sampling. Untuk variabel bebasnya adalah tipe kepribadian, sedangkan variabel terikatnya adalah prestasi belajar siswa. Teknik pengumpulan data yang digunakan adalah dokumentasi, tes, dan angket.Tes yang digunakan berbentuk pilihan ganda untuk mengetahui nilai prestasi belajar matematika siswa. Sebelum digunakan untuk mengambil data dalam penelitian, instrumen tes diuji terlebih dahulu. Untuk instrumen tes, uji tersebut meliputi uji validitas isi, perhitungan daya beda dan indeks kesukaran serta uji reliabilitas. Angket digunakan untuk mengetahui tipe kepribadian siswa. Angket yang digunakan diadopsi dari buku Personality Plus karangan Littauer, yang disesuaikan untuk siswa sekolah menengah. Tes ini mempunyai 40 kriteria kepribadian siswa, masing-masing kriteria kepribadian 
terdapat 4 pilihan pernyataan yang dapat dipilih sesuai dengan karakter kepribadian siswa berupa kekuatan dan kelemahan seseorang. Lembar penilaian angket penelitian untuk tipe kepribadian dapat dilihat pada Tabel 1 dan 2 .

Tabel 1. Lembar Penilaian Tipe Kepribadian Dilihat dari Kekuatan

\begin{tabular}{ccccc}
\hline \multirow{2}{*}{ No } & \multicolumn{4}{c}{ Kekuatan } \\
\cline { 2 - 5 } & Sanguinis & Koleris & Melankolis & Plegmatis \\
\hline 1 & Animated & Adventurous & Analytical & Adaptable \\
2 & Playful & Persuasive & Persistent & Peaceful \\
3 & Sociable & Strong-willed & Self-sacrificing & Submissive \\
4 & Convincing & Competitive & Considerate & Controlled \\
5 & Refreshing & Resourceful & Respectful & Reserved \\
6 & Spirited & Self-reliant & Sensitive & Satisfied \\
7 & Promoter & Positive & Planner & Patient \\
8 & Spontaneous & Sure & Scheduled & Shy \\
9 & Optimistic & Outspoken & Orderly & Obliging \\
10 & Funny & Forceful & Faithful & Friendly \\
11 & Delightful & Daring & Detailed & Diplomatic \\
12 & Cheerful & Confident & Cultured & Consistent \\
13 & Inspiring & Independent & Idealistic & Inoffensive \\
14 & Demonstrative & Decisive & Deep & Dry humor \\
15 & Mixes easily & Mover & Musical & Mediator \\
16 & Talker & Tenacious & Thoughtful & Tolerant \\
17 & Lively & Leader & Loyal & Listener \\
18 & Cute & Chief & Chartmaker & Contented \\
19 & Popular & Productive & Perfectionist & Pleasant \\
20 & Bouncy & Bold & Behaved & Balanced \\
\hline
\end{tabular}

Tabel 2. Lembar Penilaian Tipe Kepribadian Dilihat dari Kelemahan

\begin{tabular}{ccccc}
\hline \multirow{2}{*}{$N o$} & \multicolumn{4}{c}{ Kelemahan } \\
\cline { 2 - 5 } & Sanguinis & Koleris & Melankolis & Plegmatis \\
\hline 1 & Brassy & Bossy & Bashful & Blank \\
2 & Un disciplined & Unsympathetic & Unforgiving & Un enthusiastic \\
3 & Repetitious & Resistant & Resentful & Reticent \\
4 & Forgetful & Frank & Fussy & Fearful \\
5 & Interrups & Impatient & Insecure & Indecisive \\
6 & Un predictable & Unaffectionate & Unpopular & Uninvolved \\
7 & Haphazard & Headstrong & Hard to please & Hesitant \\
8 & Permissive & Proud & Pessimistic & Plain \\
9 & Angered easily & Argumentative & Alienated & Aimless \\
10 & Nä̈ve & Nervy & Negative attitude & Nonchalant \\
11 & Wants credit & Workaholic & Withdrawn & Worrier \\
12 & Talkative & Tactless & Too sensitive & Timid \\
13 & Dis-organized & Domineering & Depressed & Doubtful \\
14 & Inconsistent & Intolerant & Introvert & Indifferent \\
15 & Messy & Manipulative & Moody & Mumbles \\
16 & Show-offs & Stubborn & Slow & Skeptical \\
17 & Loud & Lord over & Loner & Lazy \\
18 & Scatter-brained & Short-tempered & Suspicious & Sluggish \\
19 & Restless & Rash & Revengerful & Reluctant \\
20 & Changeable & Crafty & Critical & Compromising \\
\hline
\end{tabular}


Kemudian teknik analisis data menggunakan uji analisis variansi satu jalan (One Way Anava) dengan terlebih dahulu dilakukan uji prasyarat untuk anava yaitu uji normalitas dengan metode Lilliefors dan uji homogenitas dengan uji Bartlett [6].

\section{HASIL DAN PEMBAHASAN}

Menurut hasil penelitian yang telah dilakukan menggunakan distribusi frekuensi dengan aplikasi uji statistik secara komputerisasi. Angket tipe kepribadian diberikan kepada 39 siswa dan setelah dilakukan perhitungan didapat ada 4 siswa yang masuk ke dalam 2 tipe kepribadian sehingga 4 siswa tersebut tidak dimasukkan pada analisis data. Secara lengkap distribusi frekuensi tipe kepribadian siswa dapat dilihat dari Tabel 3 berikut.

\section{Tabel 3. Distribusi Frekuensi Tipe Kepribadian Siswa}

\begin{tabular}{ccc}
\hline Tipe Kepribadian & Frekuensi & Persentase \\
\hline Sanguinis & 10 & 28,6 \\
Plegmatis & 8 & 22,9 \\
Koleris & 4 & 11,4 \\
Melankolis & 13 & 37,1 \\
\hline Total & 35 & 100
\end{tabular}

Hasil siswa yang memiliki tipe kepribadian sanguinis berjumlah 10 orang, plegmatis berjumlah 8 orang, koleris berjumlah 4 orang, dan melankolis berjumlah 13 orang. Dengan demikian, dapat disimpulkan bahwa sebagian besar siswa kelas X MIA 3 Pontianak memiliki tipe kepribadian melankolis. Prestasi belajar matematika diperoleh dengan alat ukur posttest yang terdiri dari 20 butir soal. Berdasarkan hasil penelitian perbandingan prestasi belajar siswa dapat dijelaskan pada Tabel 4 berikut.

Tabel 4. Hasil Post test

\begin{tabular}{ccccc}
\hline $\begin{array}{c}\text { Nilai Post } \\
\text { Test } \text { Siswa }\end{array}$ & $\begin{array}{c}\text { San } \\
\text { gui } \\
\text { nis }\end{array}$ & $\begin{array}{c}\text { Pleg- } \\
\text { matis }\end{array}$ & $\begin{array}{c}\text { Koler } \\
\text { is }\end{array}$ & $\begin{array}{c}\text { Melan- } \\
\text { kolis }\end{array}$ \\
\hline Tertinggi & 60 & 50 & 65 & 40 \\
Terendah & 85 & 85 & 80 & 100 \\
\hline Rata-rata & 77 & 73,75 & 75 & 73,85 \\
\hline
\end{tabular}

Pada Tabel 4 dapat dilihat perolehan prestasi belajar menggunakan rata-rata prestasi belajar dengan tipe kepribadian Sanguinis, Plegmatis, Koleris, dan Melankolis tidak terlalu berbeda atau hampir sama.

Dari data yang diperoleh, kemudian dilakukan uji normalitas dan uji homogenitas. Uji normalitas untuk prestasi belajar ditinjau dari Sanguinis, Plegmatis, Koleris, dan Melankolis, nilai probabilitasnya $>0,05$, sehingga dapat disimpulkan bahwa data prestasi belajar dalam penelitian ini berdistribusi normal. Setelah dilakukan uji normalitas, kemudian dilakukan uji homogenitas, hasil uji homogenitas diperoleh $\chi^{2}{ }_{o b s}=$ 7,760 kurang dari dengan $\chi_{0,05 ; 2}^{2}=7,815$ maka $\mathrm{H}_{0}$ tidak ditolak. Berarti variansi populasi kelompok Sanguinis, Plegmatis, Koleris, dan Melankolis sama. Sehingga dapat disimpulkan bahwa sampel berasal dari populasi yang homogen. Setelah data yang terkumpul dinyatakan berdistribusi normal dan homogen selanjutnya dilakukan pengujian hipotesis dengan uji analisis variansi satu jalan (One Way Anova) pada Tabel 5 sebagai berikut.

Tabel 5. Uji Anova Nilai Post test pada Sanguinis, Plegmatis, Koleris, dan Melankolis

\begin{tabular}{cccccc}
\hline Sumber & $\mathbf{J K}$ & $\mathbf{D k}$ & $\mathbf{R K}$ & $\mathbf{F}_{\mathbf{o b s}}$ & $\mathbf{F}_{\mathbf{0 , 0 5} \mathbf{3}, \mathbf{3 1}}$ \\
\hline Model & 69,0934 & 3 & 23,031 & $0,139:$ & 2,92 \\
Galat & 5105,192 & 31 & 164,68 & - & - \\
\hline Total & 5174,285 & 34 & - & - & - \\
\hline
\end{tabular}

Pada Tabel 5 menunjukkan $F_{\text {tabel }}>$ $F_{\text {hitung }}(2,92>0,1398)$, maka diperoleh keputusan $\mathrm{H}_{0}$ diterima yang berarti bahwa tipe kepribadian siswa tidak berpengaruh terhadap prestasi belajar matematika siswa, sehingga tidak perlu dilakukan uji lanjut Post Hoc Test dengan menggunakan metode $L S D$ karena jumlah variabel yang sama. 
Berdasarkan Tabel 5 dapat disimpulkan bahwa tidak terdapat pengaruh tipe kepribadian siswa terhadap prestasi belajar matematika siswa. Berarti siswa dengan tipe kepribadian Sanguinis, Melankolis, Koleris, maupun Plegmatis memiliki prestasi belajar matematika yang sama. Hasil penelitian ini sejalan dengan hasil penelitian yang dilakukan oleh [7] yang menyebutkan tidak ada perbedaan yang signifikan antara hasil belajar siswa yang berkepribadian ekstrovert dan introvert dan penelitian yang dilakukan oleh [8] pada siswa SMP menyimpulkan bahwa siswa dengan tipe kepribadian Sanguinis, Melankolis, Koleris, maupun Plegmatis memiliki prestasi belajar matematika yang sama.

Namun hal ini tidak sesuai dengan hipotesis awal penelitian yaitu prestasi belajar matematika siswa dengan tipe kepribadian koleris, lebih baik daripada siswa dengan tipe kepribadian sanguinis, melankolis, dan plegmatis. Siswa dengan tipe kepribadian sanguinis lebih baik prestasi belajar matematikanya daripada siswa dengan tipe kepribadian melankolis maupun plegmatis. Siswa dengan tipe kepribadian plegmatis lebih baik prestasi belajar matematikanya daripada siswa dengan tipe kepribadian melankolis. Hal ini dimungkinkan terjadi karena secara teori tipe kepribadian ini dikelompokkan berdasarkan kriteria secara umum, tidak berkaitan dengan pelajaran matematika. Hal lain yang mungkin terjadi adalah siswa belum dapat mengisi angket tipe kepribadian dengan baik dan siswa tidak objektif dalam menilai dirinya sendiri karena siswa sekolah menengah atas masih sulit untuk memahami karakter diri mereka masing-masing.

\section{SIMPULAN}

Berdasarkan hasil analisis data dan pembahasan yang telah diuraikan maka dapat ditarik kesimpulan bahwa tidak terdapat pengaruh tipe kepribadian siswa terhadap prestasi belajar matematika siswa. Berarti siswa dengan tipe kepribadian Sanguinis, Melankolis, Koleris, maupun Plegmatis memiliki prestasi belajar matematika yang sama. Dibuktikan dari hasil analisis diperoleh $f_{\text {hitung }}=0,139<$ $f_{\text {tabel }}=2,92$.

Berikut adalah beberapa hal yang dapat disarankan yaitu sekolah diharapkan dapat membantu siswa dengan tipe kepribadian Sanguinis, Melankolis, Koleris, maupun Plegmatis agar mampu bersaing dengan teman lainnya dan memperhatikan faktorfaktor psikologis siswa, guru juga diharapkan mampu membangun kedekatan emosional dengan siswa agar siswa merasa nyaman dalam mengikuti pelajaran, sedangkan bagi peneliti selanjutnya yang tertarik dengan topik yang sama disarankan untuk mengembangkan pengetahuan tentang tipe kepribadian Sanguinis, Melankolis, Koleris, maupun Plegmatis dalam ruang lingkup yang lebih luas, misalnya faktor-faktor lain yang dipengaruhi olehtipe kepribadian Sanguinis, Melankolis, Koleris, maupun Plegmatis dalam pengaruhnya terhadap penyesuaian diri.

\section{DAFTAR PUSTAKA}

[1] S. Suryabrata. Psikologi Pendidikan. Jakarta: PT. RajaGrafindo Persada, 2010.

[2] Slameto. Belajar dan Faktor-Faktor yang Mempengaruhinya. Jakarta: Rineka Cipta, 2013.

[3] R. Paramitha. "Perbedaan Prestasi Belajar Ditinjau dari Tipe Kepribadian Ekstrovert-Introvert pada Mahasiswa Universitas Negeri Malang”. Skripsi. Program Studi Bimbingan Konseling dan Psikologi Fakultas Ilmu Pendidikan Universitas Negeri Malang. Malang, 2010.

[4] A. P. Christian. "Analisis Prestasi Belajar Matematika Siswa 
Berkepribadian Introvert dan Siswa Berkepribadian Ekstrovert”. Skripsi. Program Studi Pendidikan Matematika Fakultas Keguruan dan Ilmu Pendidikan Universitas Kristen Satya Wacana. Salatiga, 2011.

[5] F. Littauer. Personality Plus: (Kepribadian Plus). Jakarta: Binarupa Aksara, 2004.

[6] Budiyono. Statistika Untuk Penelitian. Surakarta: UNS Press, 2013.

[7] H. Mularsih. "Strategi Pembelajaran, Tipe Kepribadian dan Hasil Belajar Bahasa Indonesia pada Siswa Sekolah Menengah Pertama”. Makara, Sosial Humaniora, vol. 14, no. 1, pp. 65-79, 2010.

[8] D. Septianawati. "Efektivitas Penerapan Pendekatan Matematika Realistik (PMR) dan Pendekatan Quantum Learning (QL) Ditinjau dari Tipe Kepribadian Siswa (Studi pada Siswa Kelas VIII SMP Se Kabupaten Lampung Timur Semester Ganjil Tahun Pelajaran 2012/2013)". Tesis. Universitas Sebelas Maret. Surakarta, 2013 